\title{
From fabric design to the dress manufacturing considering the fabric's suitability with the end use
}

\section{REZUMAT - ABSTRACT}

De la designul țesăturii la fabricarea rochiei, având în vedere adecvanța țesăturii la utilizarea finală

\begin{abstract}
Acest studiu investighează două țesături tip lână selectate ca fiind adecvate confecționării rochiilor pentru sezonul rece. De la început, era de așteptat ca cele două țesături să contribuie cu caracteristici diferite la fabricarea rochiilor datorită modelului și structurii diferite, fiind însă potrivite pentru utilizarea finală. Țesăturile au fost testate conform standardelor specifice pentru ansamblul proprietăților legate de purtarea reală a rochiei, unele dintre caracteristici fiind legate și de imbunătățirea aspectului general dorit de către orice clientă, indiferent de modalitatea de cumpărare a produsului (comerț cu amănuntul sau comerț electronic). Acest fapt a fost evidențiat prin intermediul unui sondaj despre preferințele femeilor cu privire la cumpărarea articolelor de îmbrăcăminte. S-a efectuat simularea 3D a produsului, datorită facilităților de vizualizare în ansamblu a rochiei create pentru sezonul rece, prin combinarea elementelor specifice schiței, materialelor (prin materia primă, model, culori și caracteristici generale preconizate la purtare) și, nu în ultimul rând, a corpului utilizatorului. Această abordare a permis trecerea de la rezultatele experimentale obținute pentru profilul calitativ estimat după testarea țesăturilor în laborator, la simularea rochiei, facilitând percepțiile virtuale ale utilizatorilor privind adecvanța țesăturilor pentru anumite creații de îmbrăcăminte. Prin urmare, în lanțul valoric textil, țesătoriile ar trebui să-și îmbunătățescă procesul de proiectare prin includerea beneficiilor simulării 3D a îmbrăcămintei. Această strategie s-ar îndrepta spre atingerea perspectivei consumatorului privind adecvanța țesăturilor pentru fabricarea articolelor de îmbrăcăminte ca produse de succes pe piață.
\end{abstract}

Cuvinte-cheie: design țesături, fabricare, confecții, destinație finală țesături, consumatori, comerț electronic

\section{From fabric design to the dress manufacturing considering the fabric's suitability with the end use}

This study covers an investigation on two wool-type fabrics selected as suitable for cold season dresses. From the beginning, it was expected that the two fabrics will bear out diverse features in dresses due to the different patterns and structures, yet suitable for the end use. The fabrics were tested following the standards for the properties linked to the actual wearing of dresses, some of the features being related also to the general appearance expected by any clothing customer, regardless of the purchasing way (retailing or e-commerce). This opinion was pointed out by a survey of women's preferences about buying clothing items. Next, it was achieved the 3D clothing simulation to visualize the cold season dress, by combining the sketch, the fabric (with raw material, pattern, colours, and overall features expected for wearing) and finally, the wearer's body. This approach allowed stepping forward from the experimental results reached for fabrics' overall quality after the laboratory testing to the dress simulation, to give customers virtual perceptions on the fabrics' suitability for particular outfits. Therefore, within the textile value chain, the weaving companies should upgrade the design process by including the benefits of the $3 D$ clothing simulation. This strategy would move towards the reaching of the consumer's perspective on the fabrics suitability for manufacturing items of clothing as successful products on the market.

Keywords: fabric design, manufacturing, clothing, fabric end use, consumers, e-commerce

\section{INTRODUCTION}

Considered a specific niche, women's clothing is strongly influenced by trends in colors, pattern and fashion but also by the feelings about an adequate durability, a satisfactory degree of comfort in wearing and finally, yet importantly, a great aesthetic appearance, no matter what the end use is [1-4]. When the garment quality for women is defined from the weaving companies' perspective, there is a focus on the overall features that can be measured in a laboratory [5-6]. Nevertheless, a perspective acknowledged as the market feedback for textile value chain, was the awareness on the women's perspective on quality, as the consumer's viewpoint [1-6]. Therefore, predicting the overall suitability for designed end use and the products success on the market can be a hard topic for fabrics and clothing manufacturers and for retailers, thus, the improving of the fabric design strategy should be the main mandatory task in textile companies [3, 6-8].

Earlier papers investigated the relationship between the lifestyle and assessment criteria for clothing purchase $[1,4,7]$. The need for manufacturers and retailers to be aware of consumers perceptions when predicting the garment' overall quality and on the garment end-use was highlighted, and this approach should be mandatory at an early stage of the development of the textile value chain. A permanent concern of weaving companies is that even though the compliance with customers' quality specifications is beneficial, this does not guarantee achieving the consumer's idea of the overall quality. One reason is the 
"feeling" the consumer has when buying an item of clothing, starting with the unambiguous expectations about the product. It is worth mentioning that the consumer's impression of a woven fabric and/or clothing item is strongly influenced by the aesthetic properties perceived visually [1-2, 6-8]. The situation becomes more complex when it comes to a successful product for e-commerce and online shopping [1, 4, 9-10].

A positive effect of the globalized market is the "consumer market without frontiers", hence, in the clothing manufacturing sector, several changes came out $[3,8]$. One of these is e-commerce, the most common form of distance shopping, which added another dimension to the textile value chain. At the beginning, the e-commerce strategy aim was to bypass retailers and reach the consumers directly, but this trend affected the clothing sector, where online sales increased more and more in the last decade. All over the world, online sellers seek to offer items of clothing in larger assortments and, generally, at better prices than traditional retailers (and not only during the sales season) so, the consumers are more likely to buy apparels items online from sellers/brands, regardless of the country the products are made in. The main actors engaged in the e-commerce and online clothing sales were e-retailers, textile specialists, and non-specialists with a web store. In this context, a lot of clothing companies choose to launch their websites just like the other online fashion chains, targeting as many consumer niches or even just a dedicated niche $[9,10]$. In 2017, $64 \%$ of internet users (aged 16 to 74) in the EU-28, with a share of $50.1 \%$ female users, reported the use of e-commerce and preference for online purchases of clothes and sports goods. Due to ongoing differences in comparison to the offline retail, the global e-fashion shopping is expected to get an average annual growth rate of $14.2 \%$ by 2019 [11].

In this context, the virtual prototyping appeared as an important achievement within the manufacturing chain of garments or other textile products, to create models adapted to customers' needs. In addition, the assistance of 3D CAD systems for the virtual prototyping of garments by means of simulation helps eliminate expensive physical prototypes, being provided as an effective design tool for the apparel industry [12-14]. Therefore, this raises a new challenge for the weaving companies, given that there is a big difference between providing static images of fabrics to customers and providing them with a simulation of the material embedded in the selected item of clothing $[11,15]$.

This paper aims to investigate the possibilities of upgrading the fabric design strategy by including the $3 \mathrm{D}$ clothing simulation, in pursuing the reaching of the consumer's point of view on the wool-type fabrics suitability for manufacturing cold season dresses as a successful product on the market, also including e-commerce.

\section{MATERIALS AND METHODS}

\section{Fabrics design}

Two wool-type fabrics were chosen for this study for their suitability in the end use, which is creating dresses for the cold season (autumn to winter). Table 1 summarizes the basics of the selected fabrics, with codifications F1 and F2.

\section{Fabrics testing}

The two wool-type fabrics were tested in accordance with standards $[5,6]$ and in a conditioned atmosphere,

\begin{tabular}{|l|l|l|l|}
\hline Fabrics & \multicolumn{3}{|c|}{ (2) } \\
\hline
\end{tabular}


for the properties linked to the actual wearing of dresses: physiological characteristics (weight/mass per unit area, thickness, apparent density and water vapour permeability), aesthetic features (crease recovery, stiffness, flexibility, and dimensional stability after washing-ironing) and durability (abrasion resistance, slippage resistance of yarns at a seam in woven fabrics).

For the selected fabrics as coating materials in the cold season dresses, a consistent sampling was carried out and, when necessary (for durability and aesthetics features) the sampling on the warp and the weft directions were considered. Two of the performed tests for the assessment of fabrics' durability, need some punctual explanations about the set up and, due to the specific aspects, they are given below:

- Regarding the fabric's abrasion resistance: a controlled amount of abrasion with the same number of cycles for both fabrics (2000 cc) was performed with the Martindale abrasion tester. The abrasion test assessed the fabric's loss of mass and the change in appearance, with inspection interval at every $1000 \mathrm{cc}$; in table 4 , the abrasion resistance was assessed by the loss of fabric's mass.

- Regarding the slippage resistance of yarns at a seam in woven fabrics performed with the Mesdan Tensolab 3: after the preparation of test specimens, the standardized testing conditions were assured for fabrics with mass $\leq 320 \mathrm{~g} / \mathrm{m}^{2}$, designed for apparel (applied load $60 \mathrm{~N}$ ) and measuring the seam opening after returning to $5 \mathrm{~N}$.

\section{A survey of women's preferences when buying} items of clothing

Previously, an online consumer survey aimed at collecting information on women's behaviour when buying items of clothing was carried out between November 2016 and May 2017. The survey covered a total of 231 respondents spread over eleven EU Member States, namely: Belgium, Bulgaria, Czech Republic, Germany, Italy, Latvia, Lithuania, Northern Ireland, Poland, Romania, Serbia, Slovenia, and Turkey.

The survey was launched online (http://www.isondaje. ro/surveys), had eighteen questions and the results allowed finding some key trends that are also relevant for this paper.

\section{Dress manufacturing and consumers expectations}

The usual procedure for manufacturing fabrics for a ready-to-wear collection of clothing items includes in principle the following steps: market research on consumer niches and fashion trend analysis; product design including the 2D pattern sketches; acquisition of raw materials suitable for the final destination (fabric as coating/lining in the clothing item); sample production ("zero series"); evaluation and approval of the sample product; manufacturing of the assortment range of fabrics and finally, the distribution/sale within the textile supply chain (for garment companies)/ on the consumer market (for store retailing and e-commerce).

This textile value chain could be perfected if the fabric design would include the $3 \mathrm{D}$ garment virtual simulation. Therefore, the characteristics of the materials selected for the final product can be translated into a virtual product alternative, and a range of different items of clothing from the same fabric or a range of one item of clothing from different fabrics can be achieved. Obviously, in this manner, one can also bet on both, the fabric's success on the market and satisfying the expectations/needs of a consumer niche on a higher level.

For this paper, a 30-day free trial CLO/3D Fashion Design software [15] was downloaded and the 3D virtual simulation of a cold season dress was achieved, by including each of the two wool-type fabrics.

\section{RESULTS AND DISCUSSION}

On the fabrics features for the designed end-use In this part, it is important to keep in mind that the two wool-type fabrics chosen for the cold season dresses have identical raw material (Wool 45\%/ PES 55\%) but are quite different in terms of pattern, yarn count size and yarn density, so, it was expected to bear out distinctive features for the dresses during wearing (table 1).

Tables 2, 3 and 4 show the average values of the structural and physiological features, of the aesthetic features and of the durability features, for each wooltype fabric indented for manufacturing the cold season dresses.

It should be noted that the values obtained for the mass per square meter, for the crease recovery angle, for the dimensional stability changes and for the tensile properties are proper and meet the allowable limits imposed by the specifications.

Table 2

\begin{tabular}{|l|c|c|}
\hline \multicolumn{2}{|c|}{ FABRICS STRUCTURAL AND PHYSICAL PROPERTIES } \\
\hline Characteristics & F1 & F2 \\
\hline Mass per square meter, $\mathrm{M}\left(\mathrm{g} / \mathrm{m}^{2}\right)$ & 242 & 207 \\
\hline Thickness, $\mathrm{g}_{\mathrm{P}}(\mathrm{mm})$ & 0.82 & 0.57 \\
\hline Apparent density, $\mathrm{d}_{\mathrm{a}}\left(\mathrm{g} / \mathrm{cm}^{3}\right)$ & 0.295 & 0.363 \\
\hline Water vapor permeability, $\mathrm{Pv}(\mathrm{mg} / 24 \mathrm{~h})$ & 880 & 860 \\
\hline
\end{tabular}

In table 2, fabric F1 is slightly heavier and thicker, has a lower apparent density than fabric F2 and also has higher water vapor permeability than F2. Therefore, fabric F1 is expected to give a better comfort when wearing the dress.

As shown in table 3 and in figure 1 also, in terms of aesthetics features, fabric F2 performs a better crease recovery and has lower stiffness values than fabric F1, also providing a better dimensional stability after washing-ironing.

Fabric F1 has a greater stiffness value and almost similar values for flexibility compared to fabric F2. As a result, it is expected that fabric F2 will provide 


\begin{tabular}{|c|c|c|c|c|c|}
\hline \multicolumn{6}{|c|}{ FABRICS AESTHETICS PROPERTIES } \\
\hline \multicolumn{2}{|l|}{ Characteristics } & \multicolumn{2}{|c|}{ F1 } & \multicolumn{2}{|c|}{ F2 } \\
\hline \multicolumn{2}{|l|}{ Sampling direction } & Warp & Weft & Warp & Weft \\
\hline \multirow{2}{*}{ Crease recovery } & Recovery angle, $\alpha_{0 \min }\left({ }^{\circ}\right) ; \alpha_{30 \min }\left({ }^{\circ}\right)$ & $140 ; 148$ & $152 ; 163$ & $132 ; 169$ & $141 ; 168$ \\
\hline & Average coefficient $\lambda(\%)$ & 80 & 87.5 & 83.6 & 85.8 \\
\hline \multirow{2}{*}{ Stiffness R (mg cm) } & Axial & 224.1 & 153.2 & 88.9 & 96.8 \\
\hline & Total & \multicolumn{2}{|c|}{185.3} & \multicolumn{2}{|c|}{92.8} \\
\hline \multirow{2}{*}{ Flexibility H (\%) } & Axial & 53.9 & 62 & 56.9 & 55 \\
\hline & Total & \multicolumn{2}{|c|}{57.9} & \multicolumn{2}{|c|}{55.95} \\
\hline \multicolumn{2}{|c|}{ Dimensional stability changes after washing-ironing, $\mathrm{M}_{\mathrm{D}}(\%)$} & 0.6 & 0.8 & 0.4 & 0.4 \\
\hline
\end{tabular}

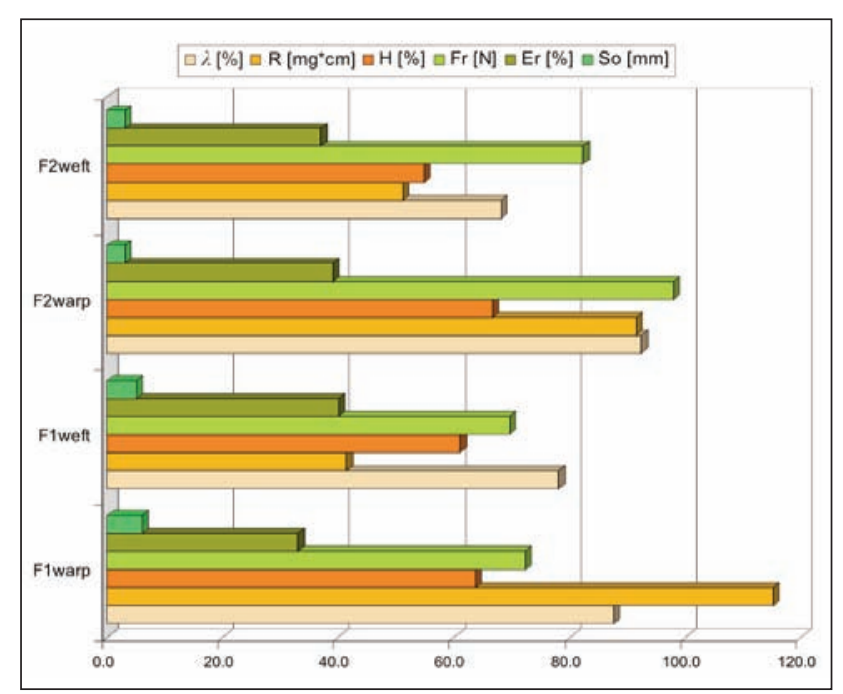

Fig. 1. Selected wool fabrics: aesthetic and durability and features depending on the threads' sampling direction (warp and weft)

better aesthetic features when wearing the dress. In addition, figure 1 shows that in terms of durability, fabric F2 performs better tensile properties than fabric $\mathrm{F} 1$, assuring a better resistance to abrasion (table 4).

Table 4

\begin{tabular}{|c|c|c|c|c|c|}
\hline \multicolumn{6}{|c|}{ FABRICS DURABILITY PROPERTIES } \\
\hline \multicolumn{2}{|l|}{ Characteristics } & \multicolumn{2}{|c|}{ F1 } & \multicolumn{2}{|c|}{ F2 } \\
\hline \multicolumn{2}{|c|}{ Sampling direction } & Warp & Weft & Warp & Weft \\
\hline \multicolumn{2}{|c|}{ Breaking force, $\operatorname{Fr}(\mathrm{N})$} & 72.3 & 69.6 & 98 & 82.3 \\
\hline \multicolumn{2}{|c|}{ Elongation, Er (\%) } & 33 & 40 & 39 & 37 \\
\hline $\begin{array}{l}\text { Loss of fabric's } \\
\text { mass, } M_{M F}(\%)\end{array}$ & $\begin{array}{l}1000 \mathrm{cc} \\
2000 \mathrm{cc}\end{array}$ & \multicolumn{2}{|c|}{$0.8 ; 0.85$} & \multicolumn{2}{|c|}{$0 ; 0$} \\
\hline \multicolumn{2}{|c|}{ Sampling direction } & Warp & Weft & Warp & Weft \\
\hline \multicolumn{2}{|c|}{ Seam opening, $S_{0}(\mathrm{~mm})$} & 6 & 5 & 3 & 3 \\
\hline
\end{tabular}

The results from the abrasion tests highlighted that a change in the mass after $1000 \mathrm{cc} / 2000 \mathrm{cc}$ was only observed for fabric F1; before reaching $2000 \mathrm{cc}$, the appearance of the fabrics changed very little by the fibers out of the flat surface but without producing the pilling. In addition, the slippage resistance of yarns at the seam has smaller values for fabric F2, regardless of the testing direction (figure 1). For fabric F1, a bigger weft slippage that the warp slippage was obtained, so was the seam opening value. Therefore, fabric F2 is expected to assure a better durability when wearing the dress.

Altogether, on the wool-type fabrics features for the designed end-use, it can be expected that fabric F1 will give a better comfort, and fabric F2 will provide better durability and aesthetic features when wearing the cold season dresses.

It remains to be seen whether dresses made from these fabrics will respond to a larger extent to women's needs as consumers and whether they will be successful for the textile supply chain.

\section{On the survey of women's preferences when purchasing clothing}

Regarding the survey, only the results that allowed naming some key trends that are relevant for the purpose of this work will be discussed, to better understand the behaviour and choices of women as clothing shoppers. The sample of consumers consisted of women aged between 18 and 60 years (with an average age of 36 years), $93.1 \%$ of them having a background in the textile field (by education in textile and professional activity).

The respondents were asked to indicate the most important factor among the nine factors considered, when deciding to purchase a clothing item and a hierarchy was obtained, as shown in figure 2 . The general appearance $(94.81 \%)$ and the quality of fabrics

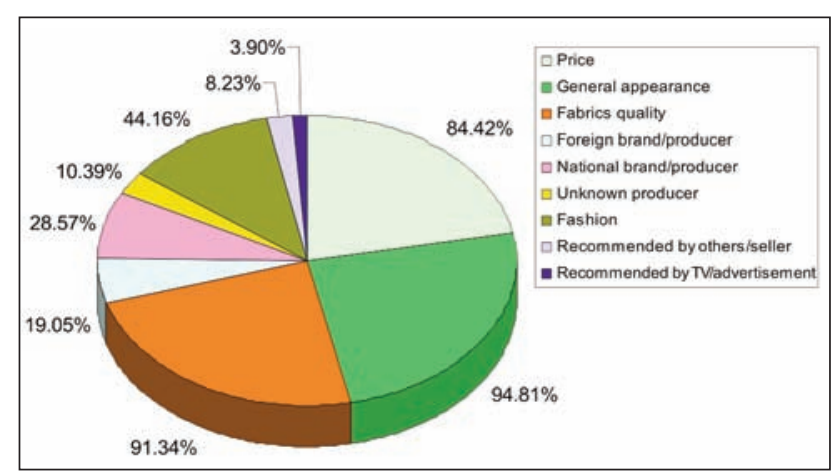

Fig. 2. Respondents sharing on the most important factor of the decision to buy clothing 

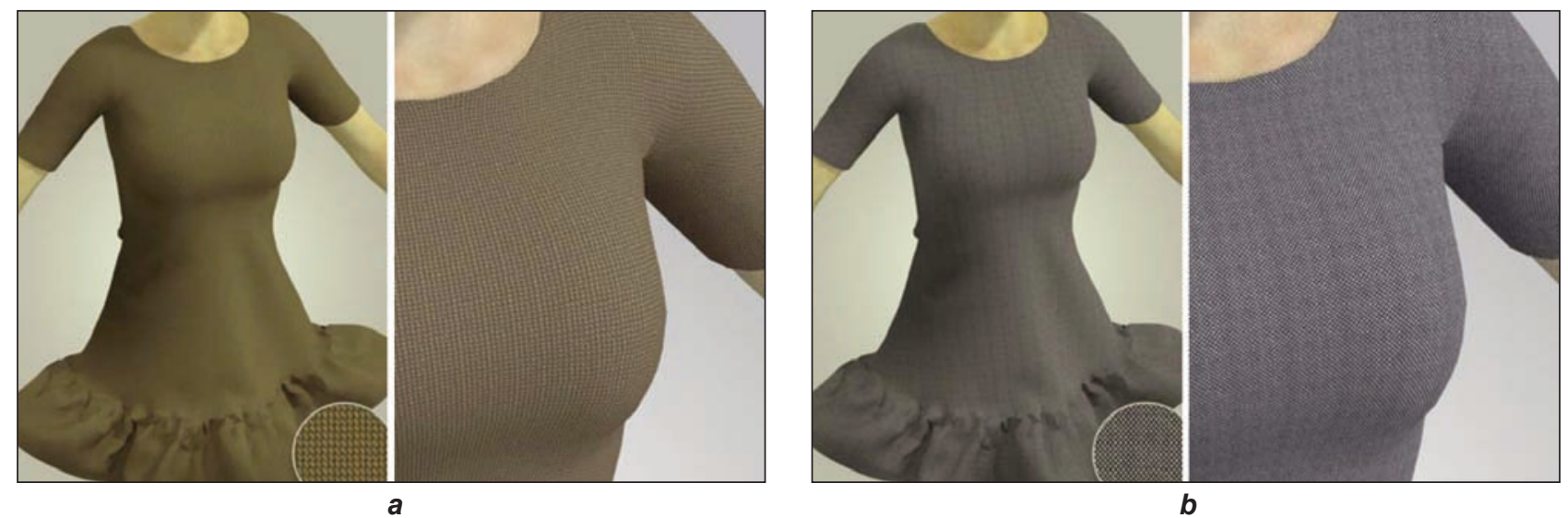

Fig. 3. The 3D simulation of dresses for cold season, made of selected wool-type fabrics: $a$ - the 3D dresses simulation with the fabric F1; $b$ - the 3D dresses simulation with the fabric F2

$(91.34 \%)$ were clearly ranked first among the most important factor for which respondents would be willing to buy a clothing item, followed by price $(84 \%$ of respondents) and by fashion $(44.16 \%$ of respondents) which had an intermediate position. A lower share of respondents is willing to purchase a clothing item considering the other factors like national brand/producer $(28.57 \%)$, foreign brand/producer $(19.05 \%)$, unknown producer $(10.39 \%)$ and recommended by others/seller (8.23\%). The lowest share of respondents $(3.90 \%)$ is willing to buy a clothing item considering the advertising strategies.

Given the basic training of respondents and the answers' relevance (with a $6.4 \%$ survey error), the ranking made by the 231 participating in the survey as potential buyers of clothes can be considered almost conclusive: the clothing appearance and the fabrics' quality could be the key factors for women willing to purchase a clothing item.

As mentioned before, the use of e-commerce and the online clothes purchases have become increasingly popular for a large segment of shoppers and, in this context, a lot of apparels companies choose to launch their websites just like the other online fashion chains. The question is whether or not the involvement in e-commerce should be a strategy also addressed by the fabrics manufacturers, which are facing a market globalization, not only within the textile value chain but as separate players too.

\section{On the dress design and consumers' niche}

As shown above, an upgraded strategy including the survey's results, should meet the needs and preferences expressed by customers. This means finding the most effective solutions that can give clients the information about the fabrics overall appearance and quality for a clothing item, and the matter here is different from providing values of the characteristics considered relevant and tested in the laboratory.

In this paper, using of the CLO3D software allowed stepping forward from the static image of fabric's sample (table 1) to the virtual simulation of fabric use (figure 3 ) enabling the upgrade of the fabric's design stage, before manufacturing the clothing item; it also should to be equally useful for e-commerce.
Figure 3 presents the images of cold season dresses (autumn to winter) made of the two wool-type fabrics. These helped to visualize the dress, by combining the sketch, the fabric (with the raw material, pattern, colors and the overall features expected for wearing) and, finally, the body.

This approach allowed stepping forward from the experimental results achieved following laboratory testing of the fabrics features, to the dress simulation to offer customers virtual perceptions on the fabrics' suitability for certain outfits.

\section{CONCLUSIONS}

In this study, an experimental investigation on two wool-type fabrics selected as suitable for cold season dresses (autumn to winter) was carried out, considering the possibility of upgrading the fabric design strategy by including the $3 \mathrm{D}$ clothing simulation, to address the wearers' preferences and needs, which are difficult to reach.

The main outcomes should support the usefulness of the subject, mainly for the fabrics producers. Regarding the online consumer survey on women's behavior when buying clothing items, out of the nine considered factors (price, general appearance, fabrics quality, foreign brand, national brand, unknown producer, fashion, recommended by others/seller and advertising), the clothing general appearance (for $94.81 \%$ of respondents) and the fabrics' quality (for $91.34 \%$ of respondents) turned out to be the key incentives for women willing to buy a clothing item. Since the fabrics' quality was considered of great importance for the consumers, the weavers should take it more into account. Considering the laboratory testing results for two wool-type fabrics made of $45 \%$ Wool / 55\% PES suitable for the end-use, a differentiation was made, given the overall qualitative profile: one of the fabrics has a better potential in terms of comfort, and the other fabric provides better aesthetic and durability features for the cold season dress. However, the most important feature for the women surveyed turned out to be the clothing general appearance. This is why, for the success of the textile value chain, the weaving companies should eventually upgrade the design strategy before manufacturing 
fabrics, by including the benefits of the 3D garment simulation, if they want to keep in mind the consumers' preferences on the fabrics' suitability for the end use. Actually, this method allowed the visualization of the dress, advancing from the static picture of a fabric's sample by combining the sketch, the fabric, and the body, in order to assess the general appearance. This approach can be useful and have great benefits in terms of efficiency all the more so today, when commerce is heavily made online. Hence, along with garment producers, the fabrics manufacturers should also consider the 3D clothing simulation when focusing on the consumer nice and want to increase the wearer's satisfaction and by default, the sales.

This work is an attempt to advance from laboratory testing of the fabrics' quality profile to reaching the clients' virtual perceptions on the fabrics' suitability for the end use, enabling them to obtain an overall appearance of two cold season dresses made from the above designed fabrics. The feedback on the fabrics suitability will consist of the preferential buying of one of the two dresses.

It is important, however, to find out if this upgraded strategy is worth the efforts, considering the overall additional costs for the fabrics producers. As a future work, the authors are considering making studies on the subjective evaluation by visualization and handling of both, fabrics and dresses made of the selected fabrics, by a panel of assessors.

\section{ACKNOWLEDGEMENT}

The authors would like to acknowledge the support of the EC Programme Erasmus+, project TexMatrix (Contract no. 2016-1-RO01-KA202-024498), as well as the financial support of Romanian Ministry of Research and Innovation, through Program 1-Development of the National R\&D System, Subprogram 1.2-Institutional Performance-Excellence Funding Projects in RDI (Contract no. 6PFE /16.10.2018).

\section{BIBLIOGRAPHY}

[1] Murali, A.L., Littrell, M.A. Consumers' perceptions of apparel quality over time: an exploratory study, In: CTRJ, 1995, vol. 13, no. 3, pp. 149-158.

[2] Tester, D., McGregor, B.A., Staynes, L. Ultrafine wools: comfort and handle properties for next-to-skin knitwear and manufacturing performance, In: Text. Res. J., 2014, vol. 85, no. 11, pp. 1181-1189.

[3] Harpa, R., Selecting wool-type fabrics for sensorial comfort in women office clothing for the cold season, using the multi-criteria decision analysis, In: IOP Conf. Ser.: Mater. Sci. Eng. 254 142009, 2017.

[4] Castelo, J.S.F., Cabral, J.E.O. Consumers in a social network: the perception of clothing quality per gender, In: Rev. Bras. Gest. Neg. - Review of Business Management, 2017, vol. 20, no. 1, p. 22-36.

[5] Saville, B.P. Physical testing of textiles, In: Woodhead Publishing Limited in association with The Textile Institute, Cambridge England, 1999.

[6] Majumdar, A. et all, Process Control in Textile Manufacturing, In: Woodhead Publishing Series in Textiles, 2013.

[7] Kanai H., Morishima M. et all, Identification of principal factors of fabric aesthetics by the evaluation from experts on textiles and from untrained consumers, In: Text. Res. J., 2011, vol. 81, no.12, pp. 1216-1225.

[8] Cassill, N., Drake, M.F. Apparel selection criteria related to female consumers' lifestyle, In: CTRJ, 1987, vol. 6, no. 1, pp. 20-28.

[9] Scheffer, M.R. Synthesis Report for the European Textile and Clothing Sector: in-depth assessment of the situation of the T\&C Sector in the EU and Prospects, 2012, European Commission.

[10] *** EUROSTAT, E-commerce statistics for individuals, http://ec.europa.eu/Eurostat, 2017.

[11] *** STATISTA, E-commerce: fashion worldwide, https://cdn.statcdn.com, 2018.

[12] Mandi, V., Ćosić, P. Integrated product and process development in collaborative virtual engineering environment, In: Technical Gazette, 2011, vol. 18, no. 3, pp. 369-378.

[13] Zhang, D., Wang, J. and Yang, Y. Design 3D garments for scanned human bodies, In: J Mech Sci Technol, 2014, vol. 28, no. 7, pp. 2479-2487.

[14] Jevšnik, S., Stjepanović, Z., Rudolf, A. 3D Virtual prototyping of garments: approaches, developments and challenges, In: JFBI, 2017, vol. 10, no. 1, pp. 51-63.

[15] ${ }^{* * *}$ CLO/3D Fashion Design Software - CLO Virtual Fashion, https://www.clo3d.com/, 2018.

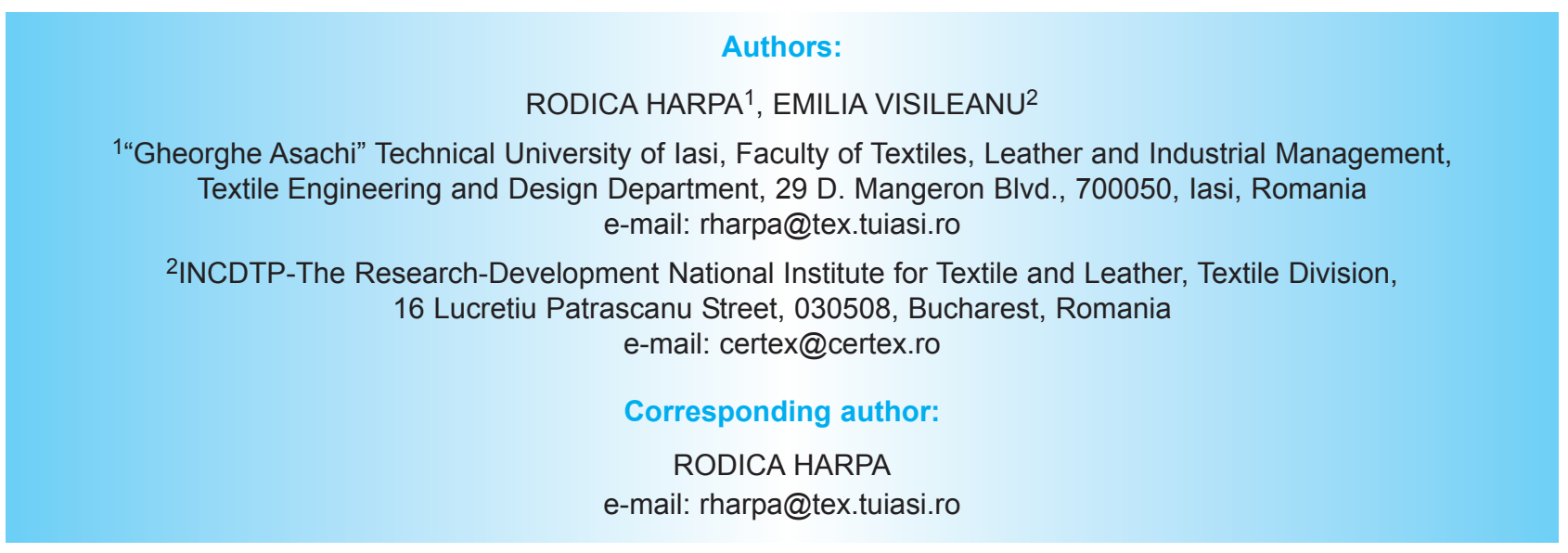

